\title{
Potential Pond Farming in the Context of Tourism
}

\author{
Milena Botlíková \\ Silesian University in, Opava, Czech Republic
}

Received: 2 November 2020. Revision received 7 February 2021. Accepted: 2 March 2021

\begin{abstract}
The article deals with the issue of a specific area of Czech cultural heritage, national and cultural identity, the phenomenon of fishing culture, and its use in the traditions and development of localities and regions in connection with tourism. The article aimed to analyze the motivating factors for visiting fishing events, attitudes towards the fish product, and the links between these factors. Cultural and historical aspects were examined mainly from the point of view of gender stereotypes and age structure, emphasizing the regional specifics of North Moravia and Silesia. 374 respondents were contacted through a questionnaire survey. The basis of the research was based on a methodological approach, quantitative research, and identification of the significance of motivational factors. The relationships between motivational factors were verified by factor analysis, comparison, and visualization performed by correspondence analysis, STATISTICA software. Research has shown that different age groups associate the term "fish" with traditional milestones, especially Christian holidays, and attributes such as Christmas fish, scales, and fish soup. In connection with tourism and cultural traditions, respondents combine fish in order to buy and taste fish dishes and the overall atmosphere. The result also showed that these products are expensive for respondents; if they were more affordable and physically available, consumers would undoubtedly increase their consumption. Research has considerable added value, which stems from the point of view of analysis in the context of cultural heritage and custom. The development of gastronomic tourism associated with fish products realized by various social events is influenced by the approach of consumers to the product and cultural customs. The sectoral synthesis in the region overlaps economically, socially, and environmentally; suppresses social and economic disparities and develops a national identity. Diversification of fishing activities is necessary to avoid risk effects.
\end{abstract}

Key Words: factor analysis, Moravian-Silesian, potential, tourism, fish.

JEL Classification: L83; Z32; C1

Reference: Milena Botlíková. (2021). Potential Pond Farming in the Context of Tourism. Journal of Tourism and Services, 20(11), 42-65. doi: 10.29036/jots.v12i22.219

\section{Introduction}

In the paper we present part of the outputs of the Program to Support Applied Research and Experimental Development of National and Cultural Identity for 2016 to 2022 (NAKI II) - Cultural traditions of Czech fishing in the light of its utilization in tourism and landscape architecture. Research is unique and incomparable because it is based on national and cultural identity, including cultural traditions and national specifics.

The motivation for this paper was also the systematic production reduction of traditional industries located in the Moravian-Silesian Region. The region's cultural tradition and cultural identity is a motivating tool for creating sources of potential prosperity that can replace existing heavy and mining industries. Cultural traditions create a potential for the tourism segment. Where cultural and natural 


\section{JOURNAL OF TOURISM AND SERVICES}

Issue 12, volume 22, ISSN 1804-5650 (Online)

www.jots.cz

monuments are not suitable, it is necessary to look for alternative elements. From this point of view, it is possible to use the potential of pond farming as a key resource for adventure and gastronomic tourism. The cultural heritage resulting from pond farming in the North Moravia and Silesia region can therefore be a driving force for prosperity, provided that suitable components of adventure tourism are identified.

The multifunctionality and tradition of the fish phenomenon in the Czech lands is centralized in pond localities, especially the Třeboň region, but there are other locations, according to Šarapatka (2014, p. 30) can be identified pond localities in Silesia and surroundings (Jistebník, Bohumín, Rychvald, Opava or Hlučín areas), to which we directed the research. A similar layout is given in Pavelková, et al. (2016, Supplemental Material).

The geographical focus of the research is based on the economic situation of the region. The development of tourism is one of the steps to reverse the long-term image of the region, namely a region of high unemployment, which will deepen as the Karviná mines begin to decline. The Strategy of the Moravian-Silesian Region for 2019 - 2027 (MSK, 2019) talks about the possibilities of regional development in connection with the use of hitherto unused attractiveness of cultural/natural values in tourism and the use of local gastronomic products/experiences and connections with visits. One of the possibilities is the use of pond sites in the region. The creation of a new tourism offer would also distribute the flows of visitors and thus facilitate today's congested mountain and foothill areas of the Jeseníky, Beskydy, and Poodř́.

The cross-sectional research is based on cultural heritage but is closely related to pond farming and the sustainability of tourism. Therefore, literature searches related to the mentioned research activities were performed too. According to (Multiannual national strategic plan for aquaculture, 2017, p. 61), the factors included in the vision of Czech fisheries until 2024 include, among others, tradition, the consumer, and the environment. The basic starting point for understanding the issue and clarifying the approach to the questionnaire part of the research is the concept of Ethnoichthyology, which is an area that examines human knowledge of fish, the use of fish and the importance of fish in different human societies and cultures.

Czech fish farming undoubtedly represents one of the parts of the Czech cultural heritage, thus contributing to creating and building national identity, helping to shape tastes, traditions, history, and landscape; this aspect significantly strengthens contacts with tourists (Green, 2017, Bjeljac, 2015). However, according to the European Parliament's Report (European Parliament, 2020), fishing capacity is not fully exploited in all regions, and it is necessary to continuously analyse the population's attitudes towards fishery products. From the point of view of domestic gastronomic tourism, development is limited by access to fish products; according to, fish consumption in the Czech Republic is below the EU level (Svoboda, 2019). The effort of the authors of this research study was to map and define the attitudes of the inhabitants of the Moravian-Silesian Region towards fish and to identify motivational factors influencing attendance in the segment of gastronomic tourism focused on fishing. The identification of attitudes predetermines the use of the necessary tools to strengthen the interest in fish gastronomy and the use of the role of local people as promoters of culinary tourism (Schmantowsky, 2014).

Despite the fact that pond farming, as a part of the agricultural sector, does not form a majority share in GDP in the Czech Republic, nor does it occupy a dominant position on the labor market, it is still necessary to take care of it. Its transformation into other areas is an important factor in the development of the national economy. The Czech Republic is an important pond region among the EU27 regions. After Finland and Hungary, the Czech Republic is the largest producer of freshwater fish: carp, barbels and other carp, and also keeps its catch in catfish catches. The significant position at the top of the EU-27 is determined by the historical development of pond farming in the Czech Republic. Historically, ponds have been associated with a waterworks and fortification function.

At present, the potential of ponds is far more diverse, they are no longer just a source of fish, but coexist and cooperate with other sectors. Many fish farms today are not only focused on fish production, 


\section{JOURNAL OF TOURISM AND SERVICES}

Issue 12, volume 22, ISSN 1804-5650 (Online)

www.jots.cz

they are also the subject of tourism, which has also stimulated the restructuring of agriculture. Fisheries enterprises seek to diversify the core business through the development of complementary activities. In the Czech Republic, five out of 42 companies are engaged in hosting or implementing social events, except for the main activities of fish farming (www.obchodnirejstrik, 2020), in another 30 fisheries, the subject of business "Production, trade and services not listed in Annexes 1 to 3 of the Trade Licensing Act "is registered, in the enumeration of which we can also find accommodation services or the operation of cultural and social events (CRM, 2020).

Czech fish are undoubtedly associated with summer recreation too. Another form of fishermen's use in connection with tourism is recreational fishing. Approximately 350.000 recreational fishermen are registered in the Czech Republic (data for 2019, All about Water, Svoboda, 2019). The trend in current recreational fishing is the preference for a catch-and-go fishing system that runs non-consumable using fishing resources. It is therefore indisputable that fishing tourism, as one of the leading ecotourism, copies the premise of sustainable tourism development and the fulfillment of one of the axes for ensuring sustainable fishing (Euro-Lex, 2007). It can be stated that locating ponds in the region has an economic, social and environmental overlap. Other activities of fishing entities include the organization of thematic socio-cultural events, cruises, gastronomic experiences, etc. Fishing can be developed in cooperation with the development of tourism by linking traditional gastronomy with fishery products and the traditional processing industry.

In addition to fish production, freshwater ponds function as valuable aquatic habitats, contribute to maintaining and enriching the quality of the ecosystem, play an important role in water and landscape management, provide services for various recreational activities and contribute to the protection of cultural heritage (Popp, 2019, p. 830). The authors also point out that while agricultural products have a well-defined market, agriculture is increasingly offering non-food services that either lack methods to determine their value or for which existing methods are imperfect. The authors introduce a relatively detailed classification by examining the hierarchical structure of multifunctional functions and its possible outputs.

\section{Literature review}

As we said before, this paper is based on cultural heritage research, ponds and fish farming research, fish products, and sustainable tourism. Therefore, searches related to the mentioned research activities were performed.

An important professional source for understanding the issue and acquainting with the literature (Svanberg 2020), where a systematic review of the literature is given, comprising 193 publications, mainly related to the topic of the relationship between man and fish in freshwater waters. As the purpose of the article (Svanberg 2020, pp.4), the authors mention the effort to review and discuss the importance of research on the relationship between humans and freshwater fish in the European context. The authors concluded that humans have always used fish and other water resources multifunctionally. However, few ethnobiologists working in Europe still study the relationship between humans and fish. The authors further state that it is important to expand ethnobiological research in Europe, thus practically supporting our research. The authors also point out the importance of folk customs and the relationship between man, landscape and fishery products (Svanberg 2020, pp. 3), thus confirming our approach to research at the level of cultural heritage. The paper presents methods and specifics of breeding in various localities, methods of capture and forms of processing and basic forms of preparation (Svanberg 2020, pp. 16-19) or recipes (Svanberg 2020, pp. 19, 20). Forms of industrial and medical use are also mentioned (Svanberg 2020 , pp. 20, 21). The mentioned source is also devoted to pond farming or recreational fishing (Svanberg 2020 , pp. 22, 23). As mentioned, it is a comprehensive source of information, the findings can also include conclusions corresponding to the basis of our research, in the publication (Svanberg 2020, p. 25) the authors state that recording knowledge passed on and still practiced by generations of fishermen and 


\section{JOURNAL OF TOURISM AND SERVICES}

Issue 12, volume 22, ISSN 1804-5650 (Online)

www.jots.cz

ethnographers or living history, are a valuable source of data that provides information on current and past fisheries policies and the human-fish relationship. Another important source of information can be Bonow, et al. (2016), where it is drawn from 120 citation sources.

In connection with the cultural identities of the Czech Republic, the fish phenomenon can be identified as a multifunctional part of culture in history and the present. The phenomenon of pond farming in the Czech Republic is so significant that it is the content of separate conferences, such as the conference "Ponds "(our heritage and wealth for the future), which has been running since 2015, currently these conferences are organized as part of the solution of the research project NAKI II DG16P02M036.

Similar foreign research includes mainly the segment of coastal states (Svanberg 2020) and deals mainly with quantitative and qualitative factors, possible traditions here stem from the source of livelihood, not from cultural traditions and customs, the standard is multifunctionality (Popp, 2019, p.832). Those interested in more in-depth information can be advised to study the materials of the Food and Agriculture Organization (FAO, a specialized agency of the United Nations), especially Manual of Running Water Fish Culture (Juanich, 1988) and History of Aquaculture (Rabanal, 1988) where you can find a detailed concept of fish farming (Rabanal, 1988, pp. 1-4).

These sources show that aquaculture in Europe started at an early stage. The residences of the ruling nobility, as well as church temples and monasteries of monks, were provided with water areas. These were later used to temporarily keep fish and were subsequently used as an area for fish cultivation. Carp and trout were recorded as the main species, which largely determined the further character of European pond farming.

The beginnings of the economic potential of fishing, which is associated with the establishment of ponds and the domestication of carp, date back to the 14th century. However, some authors differ in opinion and date the stage of establishing ponds to the 12th century. It can be stated that the pond boom in the Czech Republic took place from the middle of the 15th to the end of the 16th century, during the golden era pond farming in our territory averaged 500 ponds per year (Šarapatka, et al., 2014, p. 30). The literature provides only approximate data on the extent of ponds, in the golden era of pond farming, pond systems stretched over an area of about 180 thousand ha, in 2012 the area of all small reservoirs was estimated at about 50 thousand ha (Krrivánek, 2012), which represents 30\% of water areas of the Czech Republic.

According to Jurigová (2015, p. 40), historical and cultural values were created in this way, the identity, uniqueness and diversity of potential cultural goals were formed. The character of these goals includes art, traditions, historical estates, language, natural resources, well-established cultural background, so it co-created motifs for aquaculture travel. From this point of view, pond farming is a typical segment of cultural heritage and must be seen in analyzes as services that are mainly cultural in nature, content-oriented and less commercial (Zaman, 2015, p. 4). This author also classifies in detail the criteria for evaluating products and entrepreneurship of cultural heritage (Zaman, 2015, pp. 8-9), emphasizing multidimensionality and multi-valuedness, and lists subjectively classifiable quantities as aesthetic value as outstanding evaluation and analytical criteria; social value; economic value; environmental value; social, mental or emotional approach.

These subjectively perceived quantities and multidimensionality are potential for the development of tourism. As they state Jurigová (2015, p. 40), referring to the forecasts of "WTO Tourism: Vision 2020 "(World Trade Organization), it is necessary to understand sustainable tourism in connection with cultural heritage, cultural tourism is "one of the key segments of the tourism market in the Czech Republic".

Tourism is one of the dynamically developing sectors affecting many areas of life. New trends, such as shortening the length of stay or discovering new exotic destinations, are the focus of changes in the structure of tourism and condition the emergence of new, tourist-lucrative areas of interest in areas that are related to our basic needs, food and catering. According to López-Guzmán (2011), in the past, 


\section{JOURNAL OF TOURISM AND SERVICES}

Issue 12, volume 22, ISSN 1804-5650 (Online)

www.jots.cz

tourism was associated with one sense - sight and the tourist was just an observer. This trend is changing, tourism prefers perception through multiple senses. The perception of taste experiences was a building block for the emergence of gastronomic tourism. Food consumption is not only a basic need, but a certain expression of today's lifestyle, it forms an important part of adventure tourism. Participants in tourism focused on cultural heritage expect added value in the form of expanding the offer of specific gastronomic services or carry out trips for the purpose of a gastronomic experiment. According to Halle (2006), it was the interest of tourists, whose primary motivation is the consumption of dishes typical of the visited area that gave impetus to a new type of tourist demand, the emergence of a new type of tourism, gastronomic tourism. According to Long (1998), culinary tourism is characterized as "an activity of exploring and discovering culture and history through food that influences the formation of unforgettable experiences "but also as "tourist visits to primary or secondary producers of gastronomic events", these events are consciously sought after by tourism actors and they are willing to travel many kilometers (Niedbała, 2020). Tourists are looking for "divergence "on the target identity and culture. One such source of "diversity "is regional gastronomy (Pavlidis, 2020, p 1).

The beginnings of gastronomic tourism, as we know it today, can be dated to the $70 \mathrm{~s}$ of last century. The basis of gastronomic tourism is the tasting and consumption of local recipes, which for centuries have absorbed the traditions and customs of local people, getting acquainted with the culture of their cooking. Increasing the competitiveness of tourism through gastronomic activities represents activities such as direct sales with the possibility of subsequent processing of food (fish, meat, wine, etc.) on site, tasting, with the development of educational activities aimed at popularizing products (books, training courses, media presentations, thematic tours, etc.). It is generally known that many local and foreign visitors return to the same place to learn about cultural knowledge or taste regional specialties (Petrović, 2016; Joppe, 2001), which are mostly presented in the form of various social events of tourism. These social events (food festivals) contribute to the strengthening of social sustainability, they contribute to the interconnection of relations between diverse groups of the population (de Jong, 2018).

Regional foods can contribute to the sustainability of local cultures. According to Jemczyk (2017), culinary tourism is based on the rational and efficient use of available resources and the minimization of adverse impacts of human activities on the natural environment while meeting the social, economic and environmental needs of people and future generations. The problem, however, is that traditional dishes are being combated under the influence of globalization, which is causing the loss of local identities, or that raw materials and resources are being depleted through uncontrolled consumption. There is a positive correlation between the interest in gastronomic tourism and the maintenance and development of regional identity, the improvement of the environmental foundations of society and sustainability, the protection of traditional heritage, skills and ways of life. Tourists' interest in culinary delights, customs and culture contributes to reducing the differentiation of the social and income structure, and makes it possible to minimize economic disparities as a matter of priority in rural areas dependent on fish farming (Blacha, 2020, Kajzar, Mura, 2019).

Gastronomic tourism is closely connected with various forms of tourism, whether it is rural, social, hunting or fishing. According to the Global Report on Food Tourism (UNWTO, 2014), it forms the basis for the development of gastronomic tourism: territory, product, cultural heritage, quality, communication and sustainability. More and more destinations are realizing the importance of gastronomic tourism, organizing trips to important food holidays. Many destinations use food, hence fish products and cuisine, as a source of attraction in their tourism marketing promotion. Gastronomy, as an intangible cultural heritage, has been raised to the level of UNESCO World Heritage Sites. In this context, we cannot forget the French cuisine with the dominant Brittany and Provence cuisine. Fish foods are part of the UNESCO Mediterranean Diet (Statistical book, 2019) in countries such as Greece, Italy, Croatia and Spain. In the Czech Republic, the Třeboň pond farming was nominated in 2003 as a UNESCO World Heritage Site (Třeboň Pond Heritage). In England, fried fish and chips are a typical stereotype (Cameron, 1999). 


\section{JOURNAL OF TOURISM AND SERVICES}

Issue 12, volume 22, ISSN 1804-5650 (Online)

www.jots.cz

The connection between fisheries and tourism is intensified by the established trend in 2020, when, in connection with pandemic impacts, an increase in interest in local products is predicted. The population's interest in what they eat, focusing on a healthy diet, has increased. Consumer patterns of consumption and their eating habits related to fish are important factors influencing the demand for fish production and the attendance of gastronomic events focused on fishing. The experience with food is affected by the overall service, ie. the food itself, the place, the environment and the route of administration. Factors show that culinary gastronomic experiences are based on local, original and authentic foods that represent the local food culture (Björk, 2014). According to Devadawson (2015). The volume of fish consumption is primarily influenced by the taste and smell of fish, as well as freshness and affordability. An important aspect of motivation for consumption is compliance with ethical aspects and sustainable fishing techniques (Brecard et al., 2009). The result of the Communication Strategy (2016) shows that the barrier to fish consumption (especially from aquaculture) is the affordability and ignorance of other than traditional processing (fried fish fillet). It is still true that fish are associated with fasting, which is especially a European tradition since the Middle Ages (Poltsam-Jurjo, 2018).

If we conduct a survey of recommended statistical methods, we will use as a starting point the methods recommended for processing data in PivotTables. Many authors, for example (Sucháček, 2014), recommend determining the relationship between two or more categorical variables in a PivotTable or table system using correspondence analysis. Correspondence analysis is a multidimensional descriptive statistical method proposed by Hirschfield, and later elaborated by Greenacre (Sucháček, 2014), forming the initial structure for correspondence maps that allow to visualize and analyze questionnaire data by multiple categories.

The correspondence graph (correspondence maps) graphically displays the relationship between two variables from a PivotTable by creating a two-dimensional graph for the two strongest orthogonal factors (called dimensions) created by the decomposition of chi-square statistics.

The correspondence graph visualizes the relationship between the categories of each character separately and the two characters together. With the help of empirically derived dimensions, it is possible to monitor the spatial distribution of categories, it is possible to see which individual categories of given variables are similar and which are not (Sucháček, 2014).

Some sources (Bowman, 2017) further state that the method enables the identification of previously unobserved relationships and thus may lead to secondary testing of hypotheses. Similarly, eg (Lam, 2016) specify that factor analysis is used to examine output variables at the interval level, while correspondence analysis is used to examine categorical variables. According to (Košt'ál, 2013, p. 80), the correspondence analysis is suitable for analyzes with purely nominal variables (such as male/female, regions, etc.), with ordinal and discrete data, or for a combination of nominal and discrete data.

This analytical method is used by many authors, the effectiveness and suitability of this method for the processing of questionnaire surveys are confirmed, for example, by (Poláčková, 2010) and (Zámková, 2015). The method is recommended in cases where the respondent is offered a series of items (statements or sub-questions) to assess or agree (Košt'ál, 2013, p. 9), according to the same source (Košt'ál, 2013, p. 12) it is recommended when we examine how closely related to variables (or respondents' scores), ie how far apart the variables or cases are, which is the standard case of analyzes in the cultural heritage segment. If we compare the conclusions (Košt'ál, 2013) and (Zaman, 2015), it is clear that correspondence analysis is a suitable analytical tool for the research.

\section{Methods and data}

The methods and analyzed data are purposefully linked to research activities of the Czech cultural heritage, national and cultural identity, in a specific area of fisheries culture. This research was motivated by the specification of forms of tourism that can be an alternative to the decline of industries in the region of North Moravia and Silesia. The aim of the article was to analyze the motivating factors for visiting 


\section{JOURNAL OF TOURISM AND SERVICES}

Issue 12, volume 22, ISSN 1804-5650 (Online)

www.jots.cz

fishing events, attitudes towards the fish product and the links between these factors. Before the actual research, a research question was asked: What are the motivating factors for attending events related to fish products and their consumption.

To answer the research question, we set several hypotheses:

Hypothesis No. 1: there is a relationship between gender and the frequency of fish consumption. Hypothesis No. 2: There is a relationship between gender and attitude to the price level of fish. Hypothesis No. 3: There is a relationship between gender and the understanding of fish as a traditional dish (modern versus traditional dish).

Hypothesis No. 4: There is a relationship between gender and the motive of visiting a fish-themed event. Hypothesis No. 5: There is a relationship between the frequency of consumption and the origin of the fish.

Hypothesis No. 6: There is a relationship between gender and attitudes towards fish as a healthy food.

The research question and individual hypotheses were based on the concept published (Popp, 2019), where the authors designed a three-level structure for the analysis of pond farming in the context of cultural heritage. Multifunctional output at the highest level of the structure, functions of ponds (type of outputs) at two intermediate levels and main outputs of various functions forming the basis of the structure.

To answer this question and to analyze the hypotheses, a method of correspondence analysis was proposed. According to Komenda (2020, pp.1), testing of the statistical significance of the obtained models is not part of this analysis. The authors (Popp, 2019, pp. 838) present a comprehensive range of pond functions related to social functions, especially outputs 3.1., which specify, inter alia, recreation and tourism, recreational fishing, services for fishermen, gastronomy and outputs 3.4. - protection of cultural heritage, where the authors mention the preservation of cultural heritage, the organization of exhibitions and events, or participation in ethnographic research. These outputs were the motivation for the questionnaire survey that we conducted and were used as a supporting framework for research into the importance of pond farming in the context of cultural heritage.

Analytical methods in the field of cultural heritage have their specifics. For example, Jurigova (2015) identified indicators for these analyzes, it can be stated that these indicators are perceived quantitatively (numbers of events, numbers of people, etc.), but do not reflect subjective, in many cases unmeasurable, perception of cultural and emotional criteria.

Other authors also point out the unsystematic nature, (Marçal, et al., 2020) point out that the definition of cultural heritage does not reflect current theory or practice and suggest the use of Cultural heritage activities in NACE codes. This confirms the uniqueness of these activities and the need for specific forms of qualitative analysis focused on subjective evaluation. These conclusions made it possible to use in the questionnaire survey individual and region-specific question structures, related, for example, to price perception (see Table 2).

The data are based on a questionnaire survey in the Moravian-Silesian Region. The questionnaire consisted of items that examined the motive of attending events, the perception of fish in terms of taste and price aspects, the perception of the place itself in interaction with fish products or the perception of the origin of the product. For cost reasons (Kotler et al., 2007), the sample was created as a deliberate selection at a specific time and place. The sample size was determined using the tool http://www.raosoft.com/samplesize.html, with a 5\% error rate and 90\% confidence, the sample should contain 271 answers. A total of 374 respondents from the Moravian-Silesian Region (Moravian-Silesian Euroregion), which geographically forms one of the Euroregions of the Czech Republic, took part in the questionnaire survey. Specifically, the research was located in Rychvald fish farming (realized October 5, 2019) which is the only fish farm in the Ostrava-Karviná basin, Jistebník (realized November 10, 2019) and Dolní Benešov fish farms (realized November 2, 2019). Jistebník pond farming belongs to the largest system of ponds in the floodplain of the Odra River in the territory of our republic. The questionnaire 


\section{JOURNAL OF TOURISM AND SERVICES}

Issue 12, volume 22, ISSN 1804-5650 (Online)

www.jots.cz

survey was conducted by teachers and students of the Silesian University, and the answers were personally recorded in a printed questionnaire.

Table 1 Demographic distribution of respondents

\begin{tabular}{|l|r|r|r|r|r|r|r|r|}
\hline $\begin{array}{c}\text { Gender/a } \\
\text { ge group }\end{array}$ & $\begin{array}{c}\text { no } \\
\text { specifie } \\
\mathbf{d}\end{array}$ & $<\mathbf{2 0}$ & $\mathbf{2 1} \mathbf{- 3 0}$ & $\mathbf{3 1} \mathbf{- 4 0}$ & $\mathbf{4 1} \mathbf{- 5 0}$ & $\mathbf{5 1} \mathbf{- 6 0}$ & $>\mathbf{6 0}$ & Suma \\
\hline No specified & 6 & 0 & 2 & 0 & 0 & 0 & 0 & $\mathbf{8}$ \\
\hline Female & 62 & 10 & 26 & 30 & 24 & 28 & 6 & $\mathbf{1 8 6}$ \\
\hline Male & 44 & 12 & 24 & 36 & 22 & 34 & 8 & $\mathbf{1 8 0}$ \\
\hline Suma & $\mathbf{1 1 2}$ & $\mathbf{2 2}$ & $\mathbf{5 2}$ & $\mathbf{6 6}$ & $\mathbf{4 6}$ & $\mathbf{6 2}$ & $\mathbf{1 4}$ & $\mathbf{3 7 4}$ \\
\hline
\end{tabular}

The questions of the questionnaire were focused on the motives for participation in fishing events, the connection of fish farming with leisure activities and the identification of the fish product as a gastronomic product. In the demographic representation of respondents, we worked with the thesis that this type of activities will be used equally in both gender and age distribution, less interest is expected in the younger generation (teenager). Individual answers of respondents were processed using MS Excel Office software and subsequently exported to STATISTICA software.

Before evaluating the data from the questionnaire, we verified the reliability of the questionnaire, ie the ability of the questionnaire to reliably and accurately capture the investigated phenomena. Reliability is often defined by the correlation between a measurement and an actual value. Sufficiently high reliability is a prerequisite for good questionnaire validity, although it does not in itself guarantee validity. We express the reliability of the test by a coefficient, which has the meaning of a correlation coefficient from 0 to 1 . Reliability is a statistical characteristic that indirectly expresses the inaccuracy of the measurement

We used Cronbach's alpha to calculate reliability, which is a calculation method based on the analysis of the internal consistency of the test. Cronbach's alpha is one of the most widely used statistical tools, used mainly in the social sciences, it is a measure of reliability, specifically the internal reliability of consistency or interrelationship of questionnaire items. Internal consistency means that all items on the scale or in the test make a positive contribution to measuring the same design. Reliability is about data, not scale or forms of measurement.

Cronbach's alpha (1) usually ranges from 0 to 1 , values closer to 1 indicate greater internal consistency of variables on the scale. In other words, higher Cronbach alpha values show greater range reliability. A value of 1 means that all variability in the tests is due to actual score differences (ie reliable deviation) without measurement error. Conversely, a value of 0 means that there is no actual score (ie no reliable deviation) and that there is only a measurement error in the items. The authors (George, D, 2003) suggest a multilevel approach consisting of the following limits and ratings: " $\geq 0.9$ - Excellent, $\geq 0.8$ Good, $\geq 0.7$ - Acceptable, $\geq 0.6$ - Controversial, $\geq 0.5$ - Poor, $\leq 0.5$ - Unacceptable "(George, D, 2003, p 231). Values of $0.6 \leq \alpha<0.7$ are still considered acceptable.

$$
\propto=\frac{k}{k-1} *\left(1-\frac{\sum_{i=1}^{k} \sigma_{i}^{2}}{\sigma_{t}^{2}}\right)
$$

where: $k$ is the number of items, $\sigma_{i}^{2}$ is the variance of the $i-t h$ item and $\sigma_{t}^{2}$ is the variance of the whole test.

Various methods are used to process the questionnaires. In general, the most frequently used method are descriptive analyzes, or relational analyzes (Factor analysis, correlation analysis). Factor analysis was used for example by Björk (2014) to evaluate culinary tourism preferences.

Due to the hierarchical breakdown used in the classification and subsequently in the questionnaire survey, we used column-oriented tables structured according to the breakdown of questions and answers 


\section{JOURNAL OF TOURISM AND SERVICES}

Issue 12, volume 22, ISSN 1804-5650 (Online)

www.jots.cz

in the questionnaire survey in our research. The column-oriented data was then transformed into contingency tables (PivotTables). The PivotTable itself is suitable for measurement and test the degree of association between variables. The basic measure of the association between the two variables is the chi-square $\left(\chi^{2}\right)$ statistic, on which the nonparametric Pearson's chi-square test of independence is based.

It is a comparison of observed and expected frequencies of individual combinations of $\mathrm{X}$ and $\mathrm{Y}$. Independence, ie the validity of the null hypothesis of independence, we reject if the value of the chisquare falls in the critical range $C=[\chi(\alpha ;(\mathrm{r}-1) *(\mathrm{c}-1) ; \infty]$, where $\alpha$ represents the significance level, where $(1-\alpha)$ represents the degree of confidence and $r$ the number of variables in the rows, $c$ the number of variables in the column. The significance level $\alpha$ is usually chosen to be $0.05,0.01$ or less often 0.1 in the test (Tošenovský, 2014; Ramík, 2014, Budíková, 2010). Rahman (2020) used a reliability value of 0.05 in the analysis of the questionnaire survey, Can (2015) then tested the dependence on the reliability level of 0.05 and 0.01 . When testing the dependence, the so-called p-value is also used, which expresses the probability of receiving or exceeding the calculated test criterion. If the $\mathrm{p}$-value is less than or equal to the specified significance level, the null hypothesis is rejected. Otherwise, the null hypothesis is accepted (Tošenovský, 2014.) Rahman (2020) used a reliability value of 0.05 in the analysis of the questionnaire survey, Can (2015) then tested the dependence on the reliability level of 0.05 and 0.01 .

Correspondence analysis is a method of quantitative data analysis that allows visual identification of relationships between qualitative (categorical) variables. This analysis according to (Bowman, 2017) is closely related to chi-square statistics $\left(\chi^{2}\right)$, but it is not an inference method for direct testing of theory and hypotheses. The principle of correspondence analysis consists of the distribution of chi-square statistics calculated from a contingency table into orthogonal factors. Since correspondence analysis is only a descriptive technique, it is possible to apply it regardless of whether chi-square statistics are significant or not (Sucháček, 2014).

The correspondence analysis is a method for processing contingency tables written in the form (2) with positive values; another condition is that the row and column matrix must not be zero in the sum, ie. that the data matrix cannot be empty. The correspondence method is based similarly to factor analysis on multidimensional data matrices, it monitors the relationships between individual columns and rows. The analysis allows to describe the associations of nominal or ordinal variables and to graphically show the connections in multidimensional space.

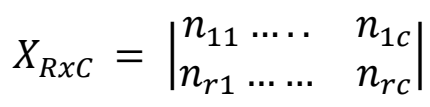

$r \times c$ represents a contingency table of two categorical variables, where $r=1, \ldots, R$ and $c=1, \ldots$, $C$, where $R$ and $C$ are the number of categories for the first and the second variable, respectively. The matrix $P_{R} x C$ is called the correspondence matrix and we calculate it as the ratio of the matrix $X_{R} x C$ and the total number of observations $\mathrm{n}(3)$

$$
n=\sum_{r=1}^{R} \sum_{c=1}^{C} n_{r c}
$$

Unlike most other multidimensional methods enables correspondence analysis of categorized processing non-metric data and nonlinear relationships. (Landau, 2004). The results of the analysis are distributed using a correspondence map. In the correspondence map, rows and columns show points. The degree of dispersion of individual points, which in the correspondence map represent row and column categories, measures the so-called total inertia. As in the case of actor analysis, it looks for a smaller number dimensions than the number of lines, or columns of the original table. Validation of row and column images, ie scatter of points, can be assessed according to the inertia indicator, which 


\section{JOURNAL OF TOURISM AND SERVICES}

Issue 12, volume 22, ISSN 1804-5650 (Online)

www.jots.cz

corresponds to the weighted average chi-square distance of row (or column) profiles from its diameter (Meloun et al. 2005).

The share of the total information on the profile, ie on the point in question $\left(\chi^{2} /\right.$ sum of all table values) represents the inertia indicator. For the correspondence analysis model, it defines the degree of scattering of points, ie row and column categories. The total inertia describes the amount of information in the table. Geometrically, inertia expresses the degree of scattering of points in multidimensional space The usual value of the inertia is at the level of $80 \%$.

\section{Results}

Based on reliability testing, it can be stated that the questionnaire survey is sufficiently consistent and reliable (Cronbach alpha $=0.695$, standardized Cronbach alpha $=0.832)$. If the values of Cronbach alpha $(1) \geq 0.7$, then it is possible to consider the reliability and at the same time the validity of the measurement based on the statement that reliability is a condition of validity (for more information Urbánek, 2011). Values of $0.6 \leq \alpha<0.7$ are still considered acceptable. Thus, the questionnaire can be considered, with reference to authors (Cho 2015; Taber, 2018; George, 2003), consistent and reliable. Cronbach alpha greater than 0.6 was recorded for all items (questions) questionnaire survey. KNOW.

The questionnaire asked questions where the respondents answered YES, NO or I DON'T

For questions related to the price level, attitudes towards the health benefits of fish and attitudes towards fish (traditional, modern, festive, ordinary), respondents assigned the adjective "Very Strong ", "Strong ", "Weak ", "Very Weak "and "None. "case. These attributes represent the weight that respondents attach to a given factor; in connection with the analysis, the attributes were quantified as follows: "Very strongly" by a value of 5 to "By no means" by a value of 1 . To the question "What is characteristic of the term fish", respondents had the opportunity to choose from a menu of 12 possible variants.

The relationships between the individual characteristics were shown using a correspondence map. All correspondence maps explain the variability contained in variables above $80 \%$, which is good in terms of maps quality. The values of chi-squares are statistically significant, ie. $\mathrm{p}$-value $<0.05$. An exception is the representation of the map of sex and frequency of consumption, variability is at the level of $62.86 \%$ (see analyzes below) and p-value $>0.05$, also in case of motivation and gender (inertia 65.04\%)

The question is whether there is a relationship between gender and attitudes towards health benefits or a relationship between gender and frequency of consumption and the origin of the fish. The following analyzes gradually evaluate the relationship between gender and health benefits, as well as the relationship between gender and tradition and the relationship between gender and price perception. These evaluations show differences in the perception of fish as a product. Furthermore, this product is analyzed from the point of view of consumption, a correlation analysis was performed between gender and frequency of consumption. Subsequently, the relationship between the frequency of consumption and the origin of the fish is analyzed.

Based on the correspondence analysis of the evaluation, it is possible to clearly observe a connection between gender and attitude to the health benefits of fish and fish products. The result of the analysis shows that the first axis of the correspondence map explains $96.21 \%$ inertia (see Figure 1), value Chi-square 172.82 and $p=0.0000$. It is also clear from Figure 1 that women rate fish as very healthy, while men are slightly more pessimistic. 


\section{JOURNAL OF TOURISM AND SERVICES}

Issue 12, volume 22, ISSN 1804-5650 (Online)

www.jots.cz

Figure 1. Correspondence map of the sex and health benefits of fish

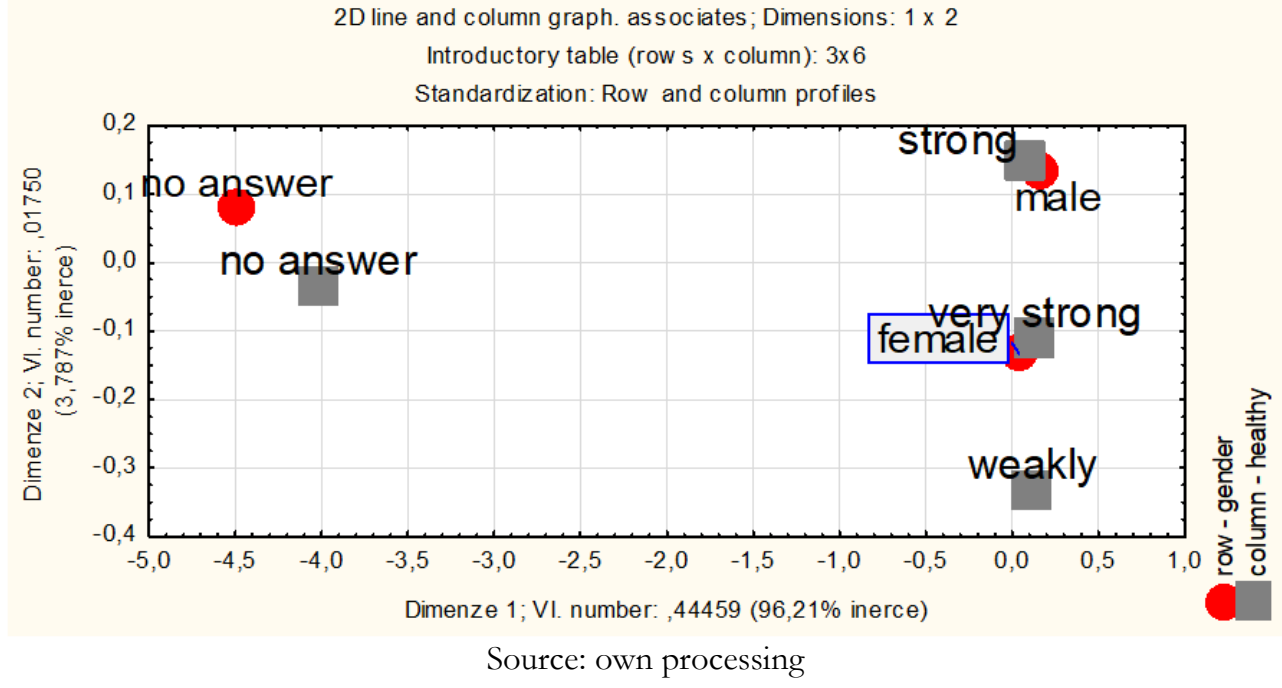

The result of the analysis shows that the first axis of the correspondence map explains $88.00 \%$ inertia (see Figure 2a), value Chi-square 75.99 and $p$-value $=0.0000$ and in the case of modern food, the value is the total inertia $88.86 \%$, Chi-square 121.36 and $\mathrm{p}=0.000$ (see figure $2 \mathrm{~b}$ ). When asked if fish are a cheap item, women are more optimistic than men. The evaluation was based on questions identifying the perception of the fish as cheap and the perception of the fish as expensive. Women mostly consider fish to be on average expensive. When asked whether fish is cheap, women responded mainly with the adjective "strongly "and "weakly "(Figure 2a), and women used the adjective "weakly "and "very weakly "for the term "expensive ". Men are more critical of the price of fish products, some of them in no way see fish as cheap (see Figure 2a), on the contrary, they rate it as expensive. To the term "expensive fish expensive "(Figure 2b), men mostly attributed the adjective "very weak ", for the designation cheap fish, men used predominantly "by no means " and "very weakly "(Figure $2 \mathrm{~b})$.

Figure 2. Correspondence maps: gender and perception of the price of fish and fish products
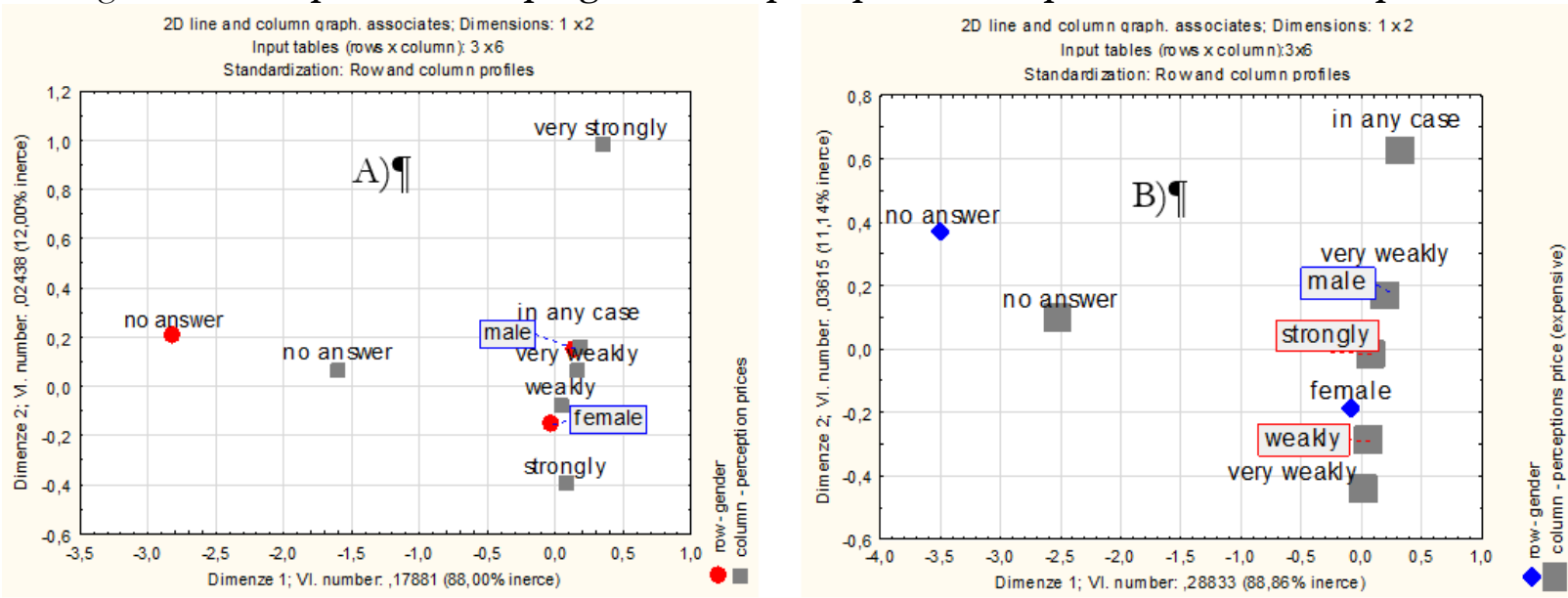

Source own processing

The result of the analysis shows that the first axis of the correspondence map explains $81.47 \%$ inertia (see Figure 3a), value Chi-square 114.49 and $\mathrm{p}=0.0$ and in the case of modern food, the value is the total inertia $83.38 \%$, Chi-square 94.68 and $\mathrm{p}$-value $=0.000$ (see figure $3 \mathrm{~b}$ ). Women consider fish to be a traditional dish, while men consider it a less traditional dish. Fish is a modern dish for respondents, 


\section{JOURNAL OF TOURISM AND SERVICES}

Issue 12, volume 22, ISSN 1804-5650 (Online)

www.jots.cz

women perceive fish more as modern, this designation is most often assigned to women by the adjective "very strongly ", men perceive fish as modern "strongly ", "weakly "and "very weakly "(Figure 3a and 3b).

Figure 3. Correspondence maps of gender and fish perception from the point of view of traditions A) and modern food B)
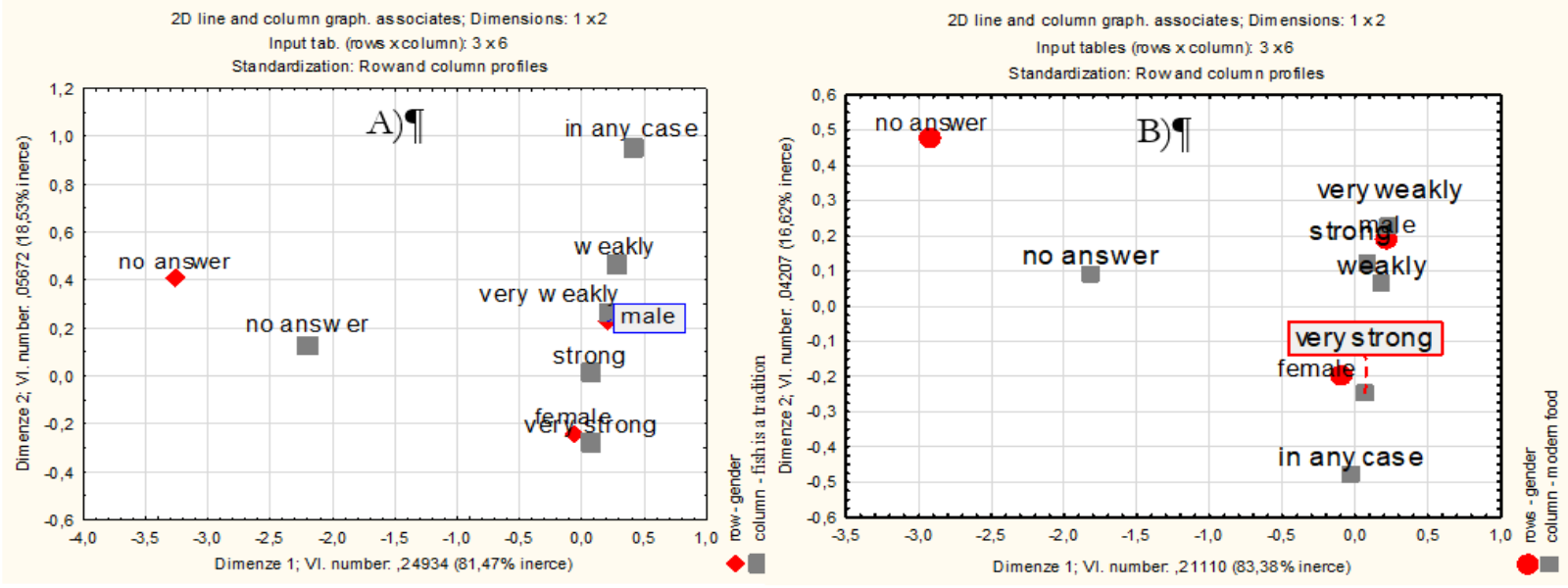

Source own processing

The result of the analysis shows that the first axis of the correspondence map explains $62.86 \%$ inertia (see Figure 4), value Chi-square 26.43 and $p=0.0032$. Women report consuming fish two to three times a week or once a month, while men eat four to seven times a week, once a week, or only occasionally. From this it can be deduced that women eat fish more often. The map showing the relationship between gender and frequency does not sufficiently explain the distribution of points in columns and rows (low value of total inertia. Therefore, it cannot confirm this statement with certainty.

Figure 4. Correspondence map correlation between gender and frequency of fish consumption

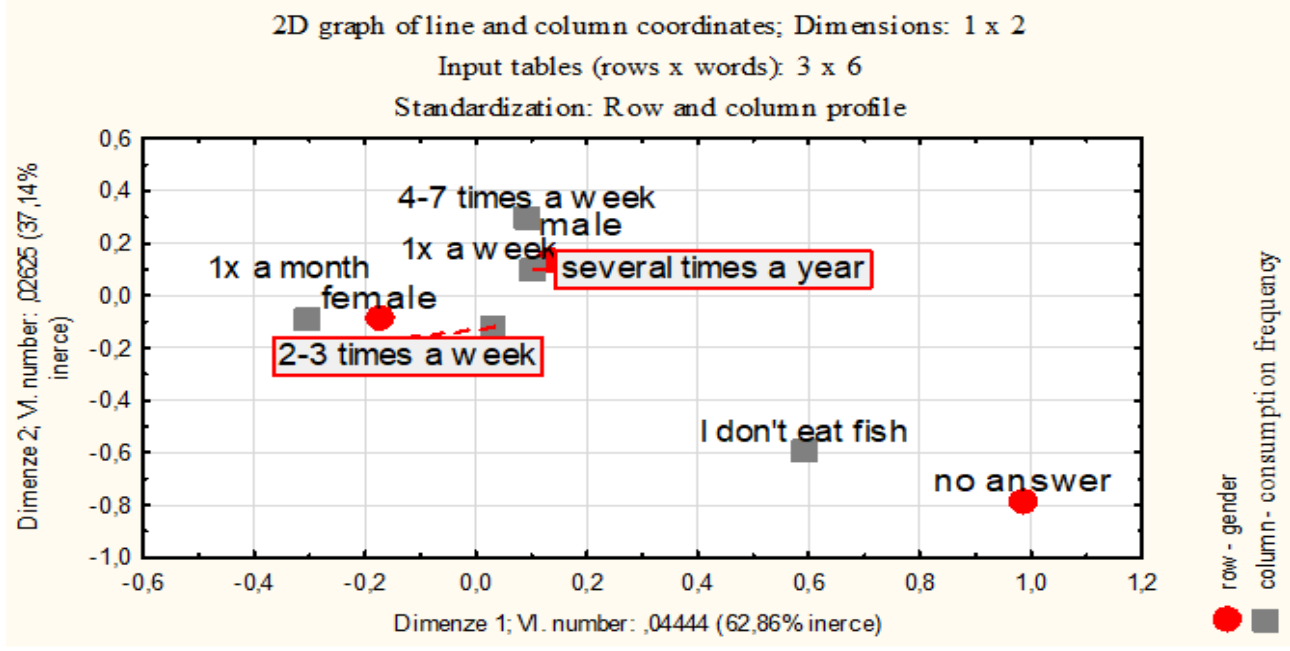

Source own processing

Figure 5 shows the frequency of consumption of individuals and locations of fish and fish products production. The first axis explains $88.18 \%$ inertia, the second axis already explains $8.21 \%$, Chisquare 143.36 and $p=0.000$. Configure maps it is obvious that people with a higher frequency of consumption (4-7 times a week and 2-3 times a week) consume fish from domestic production. People who consume fish at most once a week or monthly combine foreign and domestic products. Respondents who combine fish products into their diet only a few times a year do not usually buy fish in the same way 


\section{JOURNAL OF TOURISM AND SERVICES}

Issue 12, volume 22, ISSN 1804-5650 (Online)

www.jots.cz

as people who do not eat fish. We can assume that higher consumption stimulates domestic demand (Figure 5).

Figure 5. Correspondence map of frequency of need and origin of fish products

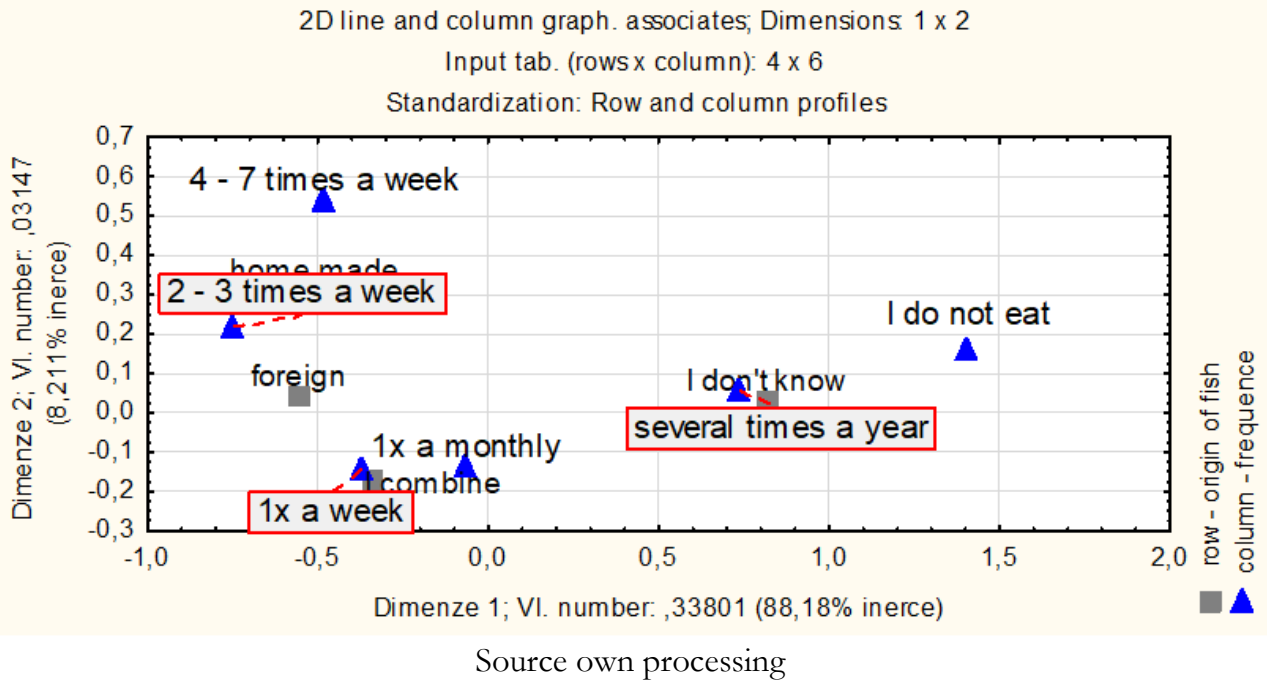

Figure 6 shows the motives for visiting a fish-focused event by gender. The first axis explains the inertia of $65.04 \%$, the second axis already explains $34.96 \%$, the square chi 28.16 and $p=0.06$. It can be seen from the picture that succumbs values are opportunities to get a recipe and fun. Motifs such as buying, tradition, tasting are attached to women in the chart.

Figure 6. Correspondence map relationship between motive and gender

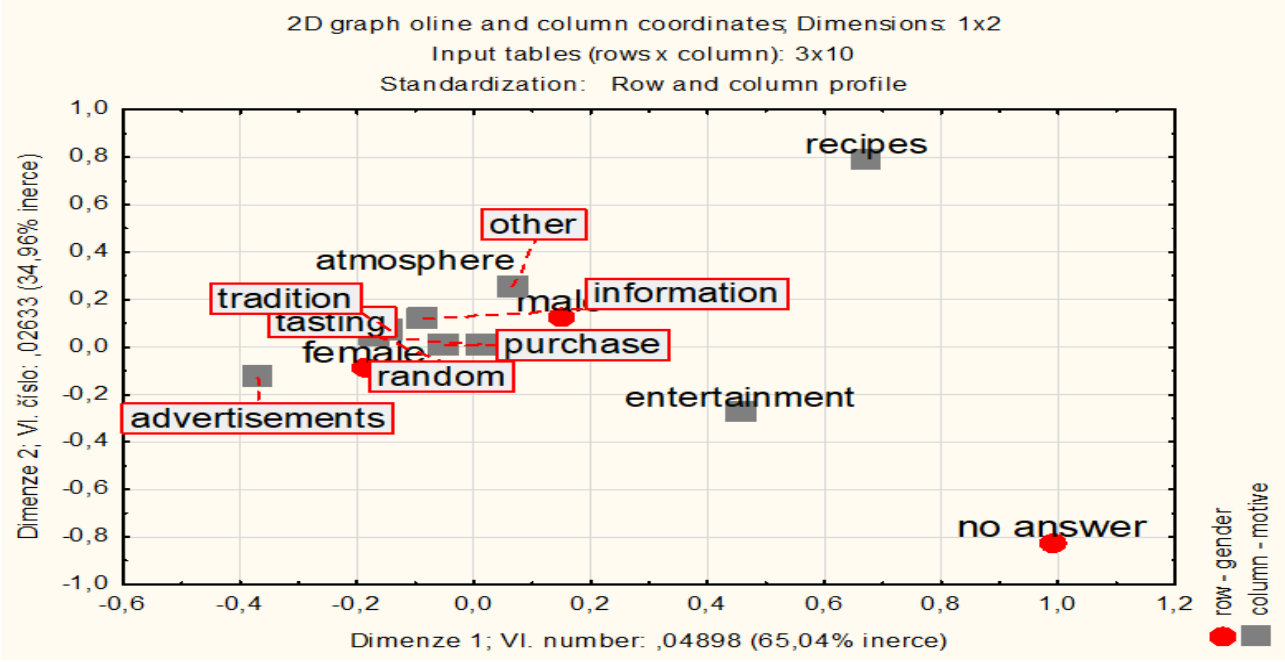

Source own processing

The men grouped together with motifs about information about fishing. It is not possible to express a relationship between motive and gender. The quality values of the map image are low, also the value of the Chi-square is lower than the critical value (28.86).

From the research, we could conclude that a typical visitor of fishing social events such as "Fishing festivals "are people who are primarily focused on buying a fish product (21\%). Approximately $41 \%$ of respondents attend similar events for the purpose of a gastronomic experience (fish tasting) or prefer the atmosphere of a fishing event. In the case of the "Fishing the pond "event, the reason for visiting was buying fish (50\% of visitors) and tasting food (approx. $9 \%$ ) prevailed. The secondary motive 


\section{JOURNAL OF TOURISM AND SERVICES}

Issue 12, volume 22, ISSN 1804-5650 (Online)

www.jots.cz

for attendance at the "Fish Festival" event was entertainment (13\%), at the "Fishing the Pond "event it was the atmosphere at the event $(19 \%)$.

The gastronomic experience is preferred by women, men attend similar events in order to purchase the product. If we evaluate age preferences, then middle-aged respondents state the purchase of products, obtaining recipes and tasting as a reason for attending events, younger respondents are motivated by entertainment options. Among the respondents, fish and fish products are mainly associated with fish farming (338 respondents), or with the landscape of ponds (316). Furthermore, among the respondents, the fish evokes tradition (284) and gastronomy (226). Very few respondents associate fish with the terms "work of art "or "advertising ". This points to the traditional understanding of fish as a gastronomic product, not as a product evoked by advertising or a means of artistic sensibility. This creates a strong potential for the use of fish products in conjunction with the traditions in the segment of experiential gastronomic tourism, even in the context of sustainability and lifestyle associated with the concept of "health ". In general, fish is classified as healthy food.

The perception of the concept of "health "in relation to fishery products in terms of age distribution showed that in the younger (up to 20 years) and older (50 years and over) age group the adjective "very strongly "even distribution. In the age group (21 - 30 years, 31-40 years), they leaned towards the adjective "strongly ". The distribution of ratings for each type of event was identical, there was no significant difference between a "pond "or a "fishing festival ", the fish was always rated as a priority as very healthy.

In connection with the concept of "health ", there is often a positive approach to concepts related to culinary experiences. In the case of the perception of the term "delicious "in fish products, no correlation was demonstrated, however, especially women rate fish more often as "very strongly "delicious, men as "strongly "delicious. Of the 356 responses, there were 10 responses that considered the fish to be "very weak" delicious and 36 to be "weakly" delicious, either those who do not eat fish or young people who are likely to condition their eating habits. or persons consuming fish only sporadically. These respondents also include people who stated that fish is "very weakly "associated with the term "disgusting "for them, which may mean that they do not associate fish with taste factors.

At present, however, about $40 \%$ of respondents from the Moravian-Silesian region (152 respondents) combine domestic and foreign fish and fish products, 72 visitors report at events focused on fish issues, consumption of fish only from domestic, ie Czech production. However, a significant proportion $(27 \% ; 102$ respondents) do not know where the products come from. A total of 22 respondents do not buy fish, of which 14 visitors do not eat fish, so they also do not buy them, in one case the respondent consumes only fish as part of his own catch. Other respondents who do not buy fish are people who consume fish only a few times a year, ie during the visit of acquaintances' parents. The trend of local foods is not reflected in the fish product in the region. The inspiration for food preparation is the Internet (162 respondents) and traditional recipes (152), which again supports the importance of the parameters "tradition "and "cultural heritage ". Women are usually inspired by the Internet and family recipes, men experiment more.

According to the respondents, fish is a traditional and festive dish. For 252 respondents, the parameter "tradition ", (or for 284 respondents the parameter "holiday ") is perceived as "very strongly "and "strongly". The generation of fish over the age of 20 understands fish as a festive or traditional meal, and the attitude of women and men is balanced. At the same time, however, fish products are considered modern (220 respondents perceive "very strongly "or "strongly "). 228 respondents do not understand fish as a normal product. From the point of view of preserving national traditions, fish has been understood as a Lenten meal since the 16th century; For the vast majority of respondents (172 respondents), fish is still associated with traditional Christmas holidays. A large group assigned to the parameter "tradition "fish scales (10 respondents), Christmas fish soup (24 respondents), which are all attributes of the Christmas holidays. From a gender point of view, Christmas is most often associated with fish with the adjective "scale "for women, and specifically for Christmas with "Christmas carp ". 


\section{JOURNAL OF TOURISM AND SERVICES}

Issue 12, volume 22, ISSN 1804-5650 (Online)

www.jots.cz

Out of 292 responses, only 18 respondents stated that they did not follow any traditions, 22 respondents stated that they traditionally consume fish at Easter, associate this product with summer grilling or consider fish as a sign of abundance and happiness. In summary, the frequencies of answers and an overview of questions are given in Table 2 .

Table 2. Questions Survey

\begin{tabular}{|c|c|c|c|c|c|c|c|c|c|}
\hline \multicolumn{10}{|c|}{ Motive for visiting a fish-themed event motive } \\
\hline Buying fish & $\begin{array}{l}\text { Tasting } \\
\text { fish }\end{array}$ & $\begin{array}{l}\text { Getting } \\
\text { recipes }\end{array}$ & $\begin{array}{c}\text { Fishing } \\
\text { information }\end{array}$ & Change & $\begin{array}{c}\text { Atmosphe } \\
\text { re }\end{array}$ & $\begin{array}{c}\text { Advertise } \\
\text { ment }\end{array}$ & $\begin{array}{c}\text { Entertain } \\
\text { ment }\end{array}$ & $\begin{array}{l}\text { Traditions } \\
\text { of the event }\end{array}$ & Other \\
\hline $34,20 \%$ & $25,10 \%$ & $2,10 \%$ & $2,10 \%$ & $4,80 \%$ & $8,60 \%$ & $2,10 \%$ & $11,20 \%$ & $7,00 \%$ & $2,70 \%$ \\
\hline \multicolumn{10}{|c|}{ What do you associate with the term fish? } \\
\hline \multicolumn{2}{|c|}{ fish breeding } & \multicolumn{2}{|c|}{ landscape } & \multicolumn{2}{|c|}{ tradition } & \multicolumn{2}{|c|}{ processing } & \multicolumn{2}{|c|}{ gastronomy } \\
\hline \multirow{2}{*}{\multicolumn{2}{|c|}{$\begin{array}{c}90,4 \% \\
\text { fishing }\end{array}$}} & \multicolumn{2}{|c|}{$84,5 \%$} & \multicolumn{2}{|c|}{$75,9 \%$} & \multicolumn{2}{|c|}{$68,7 \%$} & \multicolumn{2}{|c|}{$60,4 \%$} \\
\hline & & values & \multicolumn{2}{|c|}{ infrastructure } & \multicolumn{2}{|c|}{ personality } & publicity & school & art \\
\hline \multicolumn{2}{|c|}{$\begin{array}{l}\text { fishing } \\
57,8 \%\end{array}$} & $36,9 \%$ & \multicolumn{2}{|c|}{$28,9 \%$} & \multicolumn{2}{|c|}{$24,6 \%$} & $24,1 \%$ & $23,0 \%$ & $10,2 \%$ \\
\hline \multicolumn{10}{|c|}{ Frequency of fish consumption } \\
\hline 4-7 week & \multicolumn{2}{|c|}{$2-3$ week } & \multicolumn{2}{|c|}{ Once a week } & \multicolumn{2}{|c|}{ Once a month } & \multicolumn{2}{|c|}{ Several times a year } & Idon'teat \\
\hline $4 \%$ & \multicolumn{2}{|c|}{$14,44 \%$} & \multicolumn{2}{|c|}{$25,13 \%$} & \multicolumn{2}{|c|}{$27,27 \%$} & \multicolumn{2}{|c|}{$25,13 \%$} & $3,74 \%$ \\
\hline \multicolumn{10}{|c|}{ Origin of fish and fish products } \\
\hline \multicolumn{2}{|c|}{ domestic } & \multicolumn{2}{|c|}{ foreign } & \multicolumn{2}{|c|}{ combines } & \multicolumn{2}{|c|}{ I do not know } & \multicolumn{2}{|c|}{ does not buy fish } \\
\hline 19 & & & $9 \%$ & & $7 \%$ & & $3 \%$ & & $\%$ \\
\hline & & & & he fish $\mathrm{i}$ & s healthy & & & & \\
\hline verys & rong & & ong & & $a k$ & very & veak & & ry \\
\hline 51 & & & $3,9 \%$ & & $5 \%$ & & $\%$ & & $\%$ \\
\hline & & & & hefish is & delicious & & & & \\
\hline 40 & & & $1,7 \%$ & & $5 \%$ & & $\%$ & & $\%$ \\
\hline & & & & Fish is & cheap & & & & \\
\hline 0 , & & & $0 \%$ & & $1 \%$ & & $8 \%$ & & $2 \%$ \\
\hline & & & Fish & is a trac & itional fo & & & & \\
\hline 30 & & & $2,8 \%$ & & $2 \%$ & & $\%$ & & $\%$ \\
\hline & & & & h is a $\mathrm{m}$ & dern food & & & & \\
\hline 19 & & & $4,8 \%$ & & & & $8 \%$ & & $\%$ \\
\hline
\end{tabular}

Source: own processing

Summarizing the analysis in terms of the stated hypotheses, it can be stated that:

Hypothesis No. 1 (There is a relationship between gender and attitude to fish as a healthy meal) was confirmed, Chi-square showed dependence, although the condition was not met that $80 \%$ of expected values are greater than 5, the expected values must be greater than 2 (Tošenovský, 2014), but this condition is not required for correspondence analysis (Sucháček, 2014). The inertia is in accordance with the defined limit value when analyzing the number of axes that have cumulative inertia greater than the selected limit value, we based on the recommended limit value of 80\% (Holčík, J., Komenda, M., et al. 2015), we interpret ordination axes whose eigenvalue is above average, ie greater than the average of all eigenvalues.

Hypothesis No. 2 (There is a dependence between gender and attitude to the price level of fish) was confirmed, Chi-square showed dependence ( $80 \%$ not met). Inertia is consistent.

Hypothesis No. 3 (There is a dependence between gender and the understanding of a fish dish as a traditional dish) was confirmed, Chi-square proved addictive ( $80 \%$ not met). Inertia is consistent.

Hypothesis No. 4 (There is a relationship between gender and frequency of fish consumption) has not been confirmed. Chi-square did not show dependence, the inertia was lower than the selected limit value of $80 \%$, which means a significant variance of points in the graph.

Hypothesis No. 5 (There is a dependence between the frequency of consumption and the origin of the fish) was confirmed, Chi-square proved the dependence (not fulfilled $80 \%$ ). Inertia is consistent. 


\section{JOURNAL OF TOURISM AND SERVICES}

Issue 12, volume 22, ISSN 1804-5650 (Online)

www.jots.cz

Hypothesis No. 6 (There is a relationship between gender and the motive for visiting a fish-themed event) has not been confirmed. Chi-square did not show dependence, the inertia was lower than the selected limit value of $80 \%$.

It is clear from Graph 1 that men perceive fish as very healthy or as healthy, while women perceive fish as very healthy or unhealthy, which is probably because some women smell fish. Thus, it is clear that actions related to fishery products are generally acceptable to men, and acceptable to women unless they have other forms of antipathy to fishery products. Graph 2 shows that women do not have a strong opinion on the price of fish products, neither when called "cheap "nor "expensive ". Men do not tend to see fish as "cheap ". Graph 3 shows that women understand fish as a traditional dish. If women are to understand fish as a modern dish, then they have a very strong opinion, either "never "or "very strongly ". Men perceive fish as a modern dish less. Graph 4 shows that men have a higher tendency to consume fish, but the difference between women and men is not diametrically different. Graph 5 shows the dominant preference of domestic products or combined domestic and foreign products. According to Graph 6, men prefer atmosphere, shopping and information, women prefer traditions, choose a random approach, or are influenced by advertising.

\section{Discussion}

The aim of the research was to identify the motivations for visiting gastronomic events related to fish themes in the Moravian-Silesian Region, consumer behavior of respondents and maintaining traditions associated with fish products.

We focused on factors that are related to the understanding of fish products (price, taste, motivation, tradition, etc.), we structured according to age and gender, which is recommended, for example, by Diaconesca (2016), who states that age, gender and education are factors that influence the sustainable development of tourism and gastronomic tourism.

From the answers of the respondents it can be concluded that the situation in consumption and eating habits has not changed in any way compared to the research carried out in the past (Comunication Strategy 2016). Once a week, 94 respondents include fish or fish products in their diet, 102 respondents once a month, 94 respondents once a year. Only 70 people from the respondents consume fish several times a week, 14 people do not eat fish at all.

If we compare the results with other research, eg Rahman (2020) states that 53\% of respondents (similarly to our research) consume fish because they are healthy. However, the frequency of consumption of fish products deviates significantly from our research. Rahman (2020) uses Chi-square evaluation methods to evaluate relationships, states in his research that about $35 \%$ of respondents consume fish several times a week (19\% in our research) and $29.63 \%$ said that it fish eat once a month. Rahman (2020) further states that there is a linear relationship between frequency of consumption and education, more educated people consume more fish - more educated people are more based on a healthy lifestyle. Like Rahman (2020), we can state that men consume fish more often than women . According to Dasguptaet et al., (2017) this is because a man is mostly involved in buying fish and as the head of the family usually consumes more fish, while a woman is only involved in preparing fish for consumption. In contrast, Lucky et al. (2004) found that in Bangladesh, women consume more fish than men. Here, too, we can lean towards the claim that in the sample of the questionnaire survey there was a higher proportion of men who consumed fish sporadically only a few times a year.

Similar results have been reported in Belgium, Denmark and the Netherlands (Pieniak et al., 2008) where residents consume fish more than once a week. Milong et al. (2019) found that $40 \%$ of respondents consume fish 3-4 times a week. It is recognized that the level of education and income group may influence the level of consumption of fish products (Burger et al., 1999; Hicks et al., 2008).

According to research results, more promotion and more events related to gastronomic experiences could significantly influence these values (see the relationship between events and attendance 


\section{JOURNAL OF TOURISM AND SERVICES}

Issue 12, volume 22, ISSN 1804-5650 (Online)

www.jots.cz

to purchased products or awareness in the relationship "delicious "- "healthy "), eventually, a stronger motivation would be created resulting from the awareness of cultural heritage and traditions (fish and Christmas, fish and holidays, fish and Old Bohemian cuisine, etc.).

Motivation based on traditions is also supported by Zelený et al. (2017), which considers carp to be a reflection of fish culture in the Czech Republic. It is still widely used in families for the housewife to put fish scales under the plate of each family member for good luck, and also so that the family has enough next year, fish soup is part of the Christmas menu. With some caution, we can state that, similarly to the research by Santos (2020), that consumption increases during the winter months.

The traditional concept of the relationship to fish products is evident in the frequency of consumption, for example, the connection between consumption and "pond fishing "is evident in the fact that fishing is the domain of the male population, which is confirmed by lower frequency of fish consumption in women. Among male respondents, the highest proportion was those who consume fish once a week. In contrast, the highest proportion of women consumed fish once a month. The predominant approach to a healthy lifestyle (relation to the concept of "health ") in the female part of the population is then evident in the total amount, where consumption can be traced slightly more often in women than in men. This development again copies the results of the Communication Strategy research from 2016.

The health aspect and the predominance of the motivation approach from the point of view of classic "buying "and "tradition ", compared to the motivation from the point of view of "entertainment "can be deduced from the age structure of answers. The answers of 244 respondents show that the older generation is more likely to include fish in its diet. In the age group between 12 - 20 years, respondents most often report consumption once a year, between 21 - 40 years the consumption of fish products predominates either once a month or once a year, in the group 41 and more then predominates at least once a week, this result again copies the result from Strategy 2016. However, consumption in the Czech Republic is generally lower than the recommended consumption. The average consumption is $1.3 \mathrm{~kg}$ of freshwater fish plus $2.9 \mathrm{~kg}$ of marine fish (Association of Social Unions, 2019; EAGRI 2019), which is well below the world average $(20 \mathrm{~kg})$ and below the European level $(11 \mathrm{~kg})$. The recommended dose is $17 \mathrm{~kg}$ per person per year (EAGRI, 2019). It is recommended to include fish in the diet up to 2 times a week. These statistics are another supporting argument for the preference for gastronomic tourism. In particular, the possibilities and capacities of domestic production, related to the low share of freshwater fish in relation to marine ones, are evident.

From the results of the research it can be stated that the barrier of higher consumption is a higher price level of fish products. From the result of the evaluation of the price level in the form of the question "Is the fish expensive - expensive ", 288 respondents ("strongly "208 respondents) agreed with the adjective "very strongly "and "strongly ". Two thirds of respondents admitted that if fish were offered more often, they would increase their consumption. The high price and limited availability of fresh fish from domestic production were already in 2016 the main barriers to increasing fish consumption. According to the Communication Strategy 2016, price problems existed primarily at the supply chain level (restaurants, sales, manufacturing). New trends are leading to greater interest in the origin and method of breeding and cultivation of products, the trend is organic food. This fact is becoming a key factor in food selection, in many cases having a higher priority than price. Most chefs look for local food suppliers, whether they are suppliers of meat, fruit, vegetables, cheese, etc.

If we perform validity with similar events to which gastronomic experiences or the sale of fish products that can be attributed to sustainable tourism or cultural heritage are tied, we conclude that these products can be tied to a wider portfolio of offer. There are a number of events focused on gastronomic products, such as the "Prague Food Festival", the "Moravia Qualivo Food Festival" or the gastronomic festival "Taste of the Jeseníky Mountains". At these events, it is possible to identify an extensive accompanying program or focus on the regional nature of gastronomic products. There is also a clear differentiation into specific products, fish products make up a high percentage of gastro products. These 


\section{JOURNAL OF TOURISM AND SERVICES}

Issue 12, volume 22, ISSN 1804-5650 (Online)

www.jots.cz

products can be tied to a wider portfolio of offers, for example, the offer of fish specialties together with folklore traditions are part of the offer at the VOC Znojmo Wine Festival. A similar example is the Pilsen multi-genre festival "Živá ulice ", where fish products are available as an additional assortment.

Events focused on foreign fish products include "Sea Festival" on Kraví hora Brno, "Seafood festival" in Prague or "Adriatic fish festival" (Green Way, Jizera, Mladá Boleslav), and these events are characterized by a rich accompanying program and connection with the offer of other products, such as wine tasting.

Similar events are known from abroad, it is possible to name South Korean Hwacheon (27 thousand inhabitants), every year about a million participants visit the local traditional fishing festival, which brings to the local economy about 84 million US dollars a year.

However, it can be stated that in the Czech Republic the majority of events are focused on domestic fish products, the most visited are, for example, "Fish Festival "in Dobrríš, which is again associated with accompanying events, such as beer tapping, presentation of dining principles or information on which wines can best combine fish dishes. The rich accompanying program is complemented by attractions for children, such as a children's paradise, face painting or a photo booth with a fishing still life. There are many such events, as well as events related to the regional locality, such as the Gastro event "Fish specialties "at Bukovanský mlýn. Most events are associated with ponds, or with their catch, information can be found, for example, on the portal Kudyznudy.cz in the section Gourmet tourism. The events are connected with the fishing of ponds, for example the fishing of Rožmberk, they can be further expanded by accompanying events, such as the fishing of the Vrkoč pond (Pohořelicko) connected with the traditional fair. It is also possible to identify events known as meetings of fishermen with the general public, connected mainly with catches (catch of Hradecký pond in Tovačov, catch of Olšovce pond, "Hradní kaprobraní "in Bítov, catch of Šumvald pond near Uničov, etc. usually also connected with accompanying programs.

The region of North Moravia and Silesia included in the research is also characterized by a high proportion of similar events that could form the main axis of gastronomic tourism in the region. The dominant fishing event in the region is the catch of the largest pond in the Moravian-Silesian region "Bezruč "in Jistebník, which covers 75 hectares. Thousands of people attend the event every year, in addition to a number of stalls with refreshments, they can take home fresh fish. The events are rather connected with carousels and entertaining attractions, they are not gastro festival events. The catch of the Nezmar pond in Dolní Benešov, Petrova rybník in Krnov, etc. has a similar character. If we further think about the potential of fish products in connection with regional products, the Association of Regional Brands has identified in this context as regional products such as rainbow trout, as a regional food (Pstruhařství Raška, Staré Těchanovice, Opavské Slezsko), Oderský kapr, (company DENAS Ltd. in the Moravian Kravařsko region, 25 ponds, which are concentrated in five pond systems in Studénka, Albrechtičky and Nová Horka, Bartošovice, Odry and Bravantice) or Trout from Pstruží.

At the end of the discussion we can mention the paper from Zelený (2017), whose conclusions can be generalized in the context of our research. Fish has an important position in Czech gastronomy and needs to be restored. In this sense, cultural heritage and its positive effects and tourism can play a significant role, as well as a healthy and positive lifestyle based on traditions. Zelený (2017) states that fish, fish dishes and fishing communities can contribute to the creation of the region's identity, or whole states. According to the Greens, the symbolic level of gastronomy and cuisine as an way of dealing with fish plays an important role. However, Zelený finds a possible environmental and ethical prism problematic, which is mainly related to the way fish is farmed, because the principle of catching and killing fish directly at events can be frustrating. Both tourism and fish-initiated projects can have an impact on regional development. According to Zelený (2017), carp and the social institutions associated with it are a reflection of fish culinary culture in the Czech Republic. 


\section{JOURNAL OF TOURISM AND SERVICES}

Issue 12, volume 22, ISSN 1804-5650 (Online)

www.jots.cz

\section{Conclusion}

Research has shown the potential of experiential gastronomy focused on the traditional national product, which is undoubtedly the fish and fishing industry. Respondents are willing to associate this product with traditions and are willing to change habits and price priorities if experiential or culinary value is added to the product. To a large extent, this willingness is associated with the current trend of a healthy lifestyle. Even if the consumption of fish is below the world and European average, it does not mean a reluctance to consume this product. Respondents not only associate fish with ordinary food, it is understood as an above-standard and festive dish. This fact is supported not only by traditions, but also by the fact that fish, as in the case of coastal states, does not belong to the standard portfolio of food raw materials, is rather an additional assortment. The product conceived in this way has a specific utility value and can be understood as a product that enables to offer above-standard added value in connection with a specific offer.

The price offer of fish is a limiting factor in normal consumption. However, for the development of gastronomic tourism in connection with fish, the offered and accompanying services are likely to be more priority, as evidenced by the offer of accompanying activities at existing events. It is also possible to consider whether fish is not associated only with the Christmas holidays. It is also necessary to improve the promotion of events with a fishing theme, for example, in the case of the "Rychvald Fish Festival", visitors associate these events more with sales than with a culinary event. Summarizing the findings, it can be stated that the focus of possible activities on fish products related to the traditional understanding and approach to fish as a part of culture is indicated. Potential visitors prefer accompanying events more than the price criterion.

If we compare similar actions, it is clear that there is a set of actions focused on gastronomic products. There is a clear differentiation into specific products, fish products make up a high percentage of gastronomic products and are among the mainstays of a large number of gastronomic events.

Based on research and hypotheses, the following conclusions can be clearly recommended. We recommend directing future research to the issues of accompanying programs and programs for children, which would be more motivating for the participation of the female part of the population. Women, if they do not have antipathy, prefer a healthy product and a traditional treatment. Men are more motivated, because the accompanying activities are directed more at men's activities (competitions, fishing). In the case of events, neither the price nor the negative attitude towards products is a barrier to attendance, because visitors have other forms of motivation, especially in the form of experiences. Therefore, it is possible to recommend charging for some events, which would be beneficial for a specific pond farm or entity organizing this type of event.

It is essential for individual events that consumers prefer homemade fish (2-7 times a week). This results in a clear focus on events that do not unnecessarily combine forms of cuisine (national, foreign). Events need to be evenly targeted according to the requirements and attitudes of each gender and activities for children need to be added. It is necessary to focus more on the fish product as a healthy food, we recommend not to emphasize the aspect of catching and killing fish for women and children.

Research has shown that the tradition associated with fishing is still very important and needs to be preserved in the future and passed on to future generations. Traditional catches of ponds and events connected with fish gastronomy can very intensely spread the awareness of fish gastronomy. Fish dishes must be prepared in a modern way, there is an interest in trying new interesting tastes that are in line with the trend of a healthy lifestyle. Despite this fact, however, the respondents also demand traditional recipes for traditional recipes as a starting point for new trends. The importance of connecting traditions, fish products and gastronomy is also evidenced by a project called Fish on a Plate from the Ministry of Agriculture, which aims to increase the consumption of freshwater fish in the Czech Republic (Krupka, 2016). 


\section{JOURNAL OF TOURISM AND SERVICES}

Issue 12, volume 22, ISSN 1804-5650 (Online)

www.jots.cz

A healthy lifestyle is also important for many people today. This is reflected in regular exercise, quality nutrition, and mental well-being, so people consider fish products as an important source of beneficial nutrients.

\section{Acknowledgments}

The paper was prepared within the solution of project No. DG18P02OVV057 from the program to support applied research and experimental development of national and cultural identity for the years 2016 to 2022 (NAKI II) at the Faculty of Philosophy and Science at Silesian University in Opava.

\section{References}

1. Bjeljac, Ž., Petrović, D.M., Terzić, A. (2016). Gastronomic events as a part of tourist offer: a case study of Serbia. Agricultural bulletin of Stavropol Region, 4(24)/2 Supplement, 9-12.

2. Björk, P., Kauppinen-Räisänen, H. (2014). Culinary-gastronomic tourism - a search for local food experiences. Journal Nutrition and food sciences, 44(4), 294-309. doi 10.1108/NFS-12-20130142.

3. Blacha, L., Galmarini, MR. (2020). Rural tourism in Lobos (Argentina): Local development in the agri-food process. Pasos-Revista De Turismo Y Patrimonio Cultural, 18(2), 265-277. doi: 10.25145/j.pasos.2020.18.018.

4. Bonow, M., Olsén, H., Svanberg, I. (2016). Historical Aquaculture in Northern Europe. Stockholm: Landers.

5. Bowman, N. (2017). The SAGE Encyclopedia of Communication Research Methods. I Research, Inspirations for. Thousand Oaks: SAGE Publications, Inc.

6. Brécard, D. et al. (2009). Determinants of demand for green products: An application to ecolabel demand for fish in Europe. Journal Ecological Economics, 69(1), 115-125. doi: 10.1016/j.ecolecon.2009.07.017.

7. Budíková, M., Králová, M., Maroš, M. (2010). Průvodce základními statistickými metodami. Praha: Publishing Grada.

8. Burger, J., Stephens, W.L., Boring, C.S., Kuklinski, M., Gibbons, J.W., Gochfeld, M. (1999). Factors in exposure assessment: ethnic and socioeconomic differences in fishing and consumption of fish caught along the savannah river. Risk Anal, 19(3), 427-438. doi $10.1023 / \mathrm{a}: 1007048628467$.

9. Cameron, K. (1999). National identity. Exeter, England: Intellect.

10. Can, M.F., A. Günlü, A., Can, M.Y. (2015). Socioeconomic implications of biosecurity practices in small-scale dairy farms. Food Science and Technology, 35(2), 339-346. doi doi.org/10.1590/1678457X.6624.

11. Commercial Register. (CRM). Seznam oborü činností náležejicicich do živinosti volné, výroba, obchod a služby neuvedené v př́lohách 1 až 3 živnostenskébo zákona. Retrieved April 12, 2020, fr om https://www.mpo.cz/assets/dokumenty/28675/62240/647135/priloha021.pdf

12. Communication strategy 2016. Retrieved July 12, 2020, from https://zakazky.eagri.cz/document_ 49238/865ee9dbbd3023524d339111 ef8cd446-priloha-c-5-komunikacni-strategie-2016-pdf

13. de Jong, A., Varley, P. (2018). Food tourism and events as tools for social sustainability? Journal of Place Management and Development, 11(3), 277-295. doi: 10.1108/JPMD-06-2017-0048

14. Dasgupta, S., Mustafa, M., Paul, T., Wheeler, D., 2017. The socioeconomics of fish consumption and child health in Bangladesh. World Bank Policy Research Work Paper, 137, Article no. 8217. doi 10.1596/1813-9450-8217.

15. Devadawson, Ch., Jayasinghe, Ch., Sivakanesan, R (2015). Socio-demographic factors and fish eating trends in Eastern Community, Sri Lanka. Journal of Experimental Biology and Agricultural Sciences, 5(1), 423-429. doi: http://dx.doi.org/10.18006/2015.3(5).423.429 


\section{JOURNAL OF TOURISM AND SERVICES}

Issue 12, volume 22, ISSN 1804-5650 (Online)

www.jots.cz

16. Diaconescu, D. M., Moraru, R., Stănciulescu,G. (2016). Considerations on Gastronomic Tourism as a Component of Sustainable Local Development. Amfiteatru Economic, 18(10), IS, 999-1014.

17. European Parliament. Usneseni Evropského parlamentu ze dne 4. cervence 2017 o úloze cestovního ruchu spjatého srybolovem vdiverzifikaci odvétví rybolovu. Retrieved April 20, 2020, from https://www.europarl.europa.eu/doceo/document/TA-8-2017-0280_CS.html\#ref_1_11.

18. George, D., Mallery, P. (2003). SPSS for Windows step by step: A simple guide and reference. 11.0 update. (4th ed.). Boston: Allyn \& Bacon.

19. Cho, E., Kim, S. (2015). Cronbach's Coefficient Alpha: Well Known but Poorly Understood. Organizational Research Methods, 18(2), 207-320. doi 10.1177/1094428114555994.

20. Hall, M.C., Sharples, L., Mitchell, R., Macionis, N., Cambourne, B., (2006). Food Tourism Around the World: Development, Management and Markets. Oxford: Butterworth Heinemann.

21. Hicks, D., Pivarnik, L., McDermott, R. (2008). Consumer perceptions about seafood-aninternet survey. Journal of Foodservice. 19(4), 213-226. doi 10.1111/j.1748-0159.2008.00107.x.

22. Holčík, J., Komenda, M., kol. (2015). Matematická biologie: e-learningová učebnice [online]. Retrieved 2015, from https://portal.matematickabiologie.cz/index.php?pg=analyza-ahodnoceni-biologickych-dat--vicerozmerne-metody-pro-analyzu-dat--ordinacni-analyzy-korespondencni-analyza--hodnoceni-modelu.

23. Jęczmyk, A., Kasprzak, K. (2017). Turystyka kulinarna w świetle koncepcji zrównoważonego rozwoju w Polsce. Polish Journal for Sustainable Development. vol. 21(1), 7-14. doi 10.15584/pjsd.2017.21.1.1.

24. Joppe, M., Martin, D., Waalen, J. (2001). Toronto's image as a destination: a comparative importance satisfaction analysis by origin of visitor. Journal of Travel Research, 39, 252-260. doi $10.1177 / 004728750103900302$.

25. Juanich, G. L. (1988). Manual of running water fish culture, 1. Eucheuma spp. Retrieved April 1988, from http://www.fao.org/3/AC416E/AC416E00.htm.

26. KRUPKA, J. Jurečkův resort spustil kampaň Ryba na talír Retrieved June 25, 2015, from https://www.mediar.cz/ministerstvo-zemedelstvi-spustilo-rybi-kampan/

27. Jurigova, Z., Lencsesova, Z. (2015). Monitoring System of Sustainable Development in Cultural and Mountain Tourism Destinations. Journal of Competitiveness, 7(1), 35-52. doi 10.7441/joc.2015.01.03.

28. Kitano, Sh., Yamamoto, N. (2020). The role of consumer knowledge, experience, and heterogeneity in fish consumption: Policy lessons from Japan. Journal of Retailing and Consumer Services, 56, Article no. 102151. Doi 10.1016/j.jretsercon.2020.102151.

29. Komenda, M. Korespondencni_analyza_FINAL.docx. Retrieved June 20, 2020, from https://i s.muni.cz/www/98951/41610771/43823411/43823458/Analyza_a_hodnoc/44563155/

30. Košt'ál, J. (2013). Vybrané metody víceroẓmèrné statistiky (Selected multivariate statistics methods). Praha: Institut pro kriminologii a sociální prevenci.

31. Kotler, P., Wong, V., Saunders, J., Armstrong, G. (2007). Moderni marketing. Grada: Publishing a.s.

32. Křivánek, J., Němec, J., Kopp, J. (2012). Rybniky v Ceské republice. Praha: Jan Němec - Consult. .

33. Lam, Ch. (2016). Correspondence Analysis: A Statistical Technique Ripe for Technical and Professional Communication. IEEE Transactions on Professional Communication, 59(3), 299-310. doi 10.1109/TPC.2016.2583279.

34. Landau, S., Everitt, B.S. (2004). A Handbook Statistical Analyses using SPSS. London: CHAPMAN \& HALL/CRC.

35. Long, M. L. (1998). Culinary Tourism: A Folkloristic Perspective on Eating and Otherness. Southern Folklore, 55(3), 181-204. 


\section{JOURNAL OF TOURISM AND SERVICES}

Issue 12, volume 22, ISSN 1804-5650 (Online)

www.jots.cz

36. López-Guzmán, T., Sánchez-Cañizares, S. (2011). Gastronomy, Tourism and Destination Differentiation: A Case Study in Spain. Review of Economics \& Finance, 63-72.

37. Lucky, N.S., Haque, M.M.U., Hossain, M. (2004). Fish consumption pattern in three slums of Mymensingh. Progressive Agriculture, 15(2), 67 -75.

38. Marçal, E., Corr, S., Cueco, D.A., Hutchings, J., Newman, C. (2020). On the Classification of the Cultural Heritage Sector within NACE. International Journal of Cultural Heritage, 5, 23-31.

39. Meloun, M., Militký, J., Hill, M., (2005). Počitačová analýza vícerozmèrných dat v př̌keladech. Praha: Academia.

40. Milong, M.C.S., Njikoue, J.M., Leng, M.S., et al. (2019). Local Preferences and Perception towards the Consumption of Farmed Fish in the Center Region of Cameroon. International Journal of Food and Nutritional Science, 6(2), 81-88. doi 10.15436/2377-0619.19.2509.

41. MSK 2019. Development strategy of the Moravian-Silesian region 2019-2027. Retrieved August, 2020, from https://www.hrajemskrajem.cz//wp-content/uploads/2019/11/Upraven\%c3\%bdn\%c3\%a1vrh-Strategie-rozvoje-MSK-2019-2027.pdf

42. Mura, L., Kajzar, P. (2019). Small Businesses in Cultural Tourism in a Central European Country. Journal of Tourism and Services, vol. 10(19), 40-54. doi 10.29036/jots.v10i19.110.

43. Niedbała, G., Jeczmyk, A., Steppa, R., Uglis, J. (2020). Linking of Traditional Food and Tourism. The Best Pork of Wielkopolska-Culinary Tourist Trail: A Case Study. Sustainably, 12(13), Article no. 5344. doi 10.3390/su12135344.

44. Pavelková, R., Frajer, J., Havlíček, M., Netopil, P., Rozkošný, M., David, V.,Dzuráková, M., Sarapatka, B. (2016). Historical ponds of the Czech Republic: an example of the interpretation of historic maps. Journal of Maps, 12(1), 551-559. doi 10.1080/17445647.2016.1203830.

45. Pavlidis, G., Stella Markantonatou, S. (2020). Gastronomic tourism in Greece and beyond: A thorough review. International Journal of Gastronomy and Food Science, vol. 21, Article no. 100229. doi 10.1016/j.ijgfs.2020.100229.

46. Petrović, M.D. Bjeljac, Ž., Vujko, A. (2016). Analysis of the life cycle of an agritourism destination - a theoretical Approach. Agricultural bulletin of Stavropol Region, 4(24)/2, Supplement, 76-79.

47. Pieniak, Z., Verbeke, W., Perez-Cueto, F., Brunsø, K., De, H.S. (2008). Fish consumptionand its motives in households with versus without self-reported medical history ofCVD: a consumer survey fromfive European countries. BMC Publ. Health, 8, 1-14. doi 10.1186/1471-2458-8-306.

48. Poláčková, J., Jindrová, A. (2010). Vyhodnocení dotazníkového šetření pomocí korespondenční analýzy. Ekonomická Revue, 13(3), 173 - 178. doi 10.7327/cerei.2010.9.06.

49. Poltsam-Jurjo, I. (2018). On the Importance of Fish to Trade, Economy and Daily Menu in Estonia in the 13th to 16th Centuries. Acta Historica Tallinnensia, 24(1), 3-23. doi 10.3176/hist.2018.1.01.

50. Popp, J., Békefi, E., Duleba, Sz., Olah, J. (2019). Multifunctionality of pond fish farms in the opinion of the farm managers: the case of Hungary. Reviews in Aquaculture, 11, 830-847. doi $10.1111 /$ raq. 12260 .

51. Rabanal, H.R. (1988). History of Aquaculture. Retrieved April 1988, from http://www.fao.org/3/a-ag158e.pdf.

52. Rahman, N., Reza. A., Islam, T. (2020). Consumer fish consumption preferences and contributing factors: empirical evidence from Rangpur city corporation, Bangladesh. Heliyon, 6(12), Article no. e0584. doi /10.1016/j.heliyon.2020.e05864.

53. Ramík, J., Stoklasová, R. (2014). Statistika. Karviná: Slezská univerzita.

54. Santos, J.AC., Santos, M.C., Pereira, L.N., Richards, G., Caiado, L. (2020). Local food and changes in tourist eating habits in a sun-and-sea destination: a segmentation approach. International Journal of Contemporary Hospitality Management, 32(11), 3501-3521. doi 10.1108/IJCHM04-2020-0302. 


\section{JOURNAL OF TOURISM AND SERVICES}

Issue 12, volume 22, ISSN 1804-5650 (Online)

www.jots.cz

55. Schmantowsky, C. (2014). Best practices in culinary tourism. Development models and applications domestic and abroad. Boca Raton: Lynn University Publishing.

56. Statistical book: Culture statistics. Retrieved April 12, 2020, from https://ec.europa.eu/eurostat/d ocuments/3217494/10177894/KS-01-19-712-EN-N.pdf/915f828b-daae-1cca-ba54a87e90d6b68b.

57. Sucháček, J., Freidrich, V., Šed’a, P., Beníšková, T. (June, 2014). South Moravian and MoravianSilesian Region in National TV Reporting: Selected Aspects. Paper presented at the conference of XVII. mezinárodní kolokvium o regionálních vědách, Hustopeče.

58. Svanberg, I., Locker, A. (2020). Ethnoichthyology of freshwater fish in Europe: a review of vanishing traditional fisheries and their cultural significance in changing landscapes from the later medieval period with a focus on northern Europe. Journal of Ethnobiology and Ethnomedicine, 16(1), Article no. 68. doi 10.1186/s13002-020-00410-3.

59. Svoboda, M. (2019). Asociace samostatných odbori. Retrieved November 21, 2019, from https://www.asocr.cz/obsah/54/zrozeno-v-eu-kvalita-ryb-u-nas-v-zemich-eu/242994.

60. Šarapatka, B., Pavelková Chmelová, R., Frajer, J. (2014). The Development of PondManagement as an Integral Part of the Cultural Inheritance of the Czech Republic Focusing on the Situation from the Mid-19th Century. Životné prostredie, 48(1), 29 - 32.

61. Taber, K. S. (2018). The use of Cronbach's alpha when developing and reporting research instruments in science education. Research in Science Education, 48(6), 1273-1296. doi 10.1007/s11165-016-9602-2.

62. Tošenovský, F. (2014). Statistické metody pro ekonomy. Karviná: Slezská univerzita v Opavě.

63. UNWTO, Global report on food tourism. 2014. Retrieved June 20, 2020, from <http://dtxtq4w60xqpw.cloudfront.net/sites/all/files/pdf/food_tourism_report.pdf $>$

64. Urbánek, T., Denglerová, D., Širůček, J. (2011). Psychometrika: Měreni v psychologii. Praha: Portál.

65. mmw.eagri.c\%. Retrieved June 20, 2020, from http://eagri.cz/public/web/file/645372/Ryby_201 9_WEB.pdf.

66. mmw.eagri.cz. Viceletý národni strategický plán pro akvakulturu, 2014, Retrieved October 2014, from hhttp://eagri.cz/public/web/file/342863/VICELETY_STRATEGICKY_PLAN_PRO_AK VAKULTURU_20141027.pdf.

67. wnw.euro-lex-evropa.eu. Komise evropskéch spolecenstvi. Retrieved June 20, 2020, from https:/ / eurlex.europa.eu/legal-content/CS/TXT/PDF/?uri=CELEX:52007DC0575\&from=ES

68. wnw.obchodnirejstrik.c\%: Retrieved April 15, 2020, from https://or.justice.cz/ias/ui/rejstrikfirma?jenPlatne $=$ PLATNE\&nazev $=\mathrm{Ryb} \% \mathrm{C} 3 \% \mathrm{~A} 1 \% \mathrm{C} 5 \% 99 \mathrm{stv} \% \mathrm{C} 3 \% \mathrm{AD} \&$ polozek $=50 \&$ typH ledani=STARTS_WITH.

69. wnw.vseovode.c\%. Retrieved June 20, 2020, from http://www.vseovode.cz/clanek/kolik-je-v-crrybniku-rybaru.

70. Zaman, G. (2015). Cultural heritage entrepreneurship (CHE) - challenges and difficulties. Procedia - Social and Behavioral Sciences, 188(14), 3-15. doi 10.1016/j.sbspro.2015.03.333.

71. Zámková, Z., Prokop, M. (2015). Causes and Financial Consequences of Flight Delays in Czech Republic. Acta academians, 10(3), 110-120. doi 10.25142/aak.2015.036.

72. Zelený, J., Vins, Z. (2017, October). Fish, Culture and Culinary Art - Relation To Local Communities And Potential For Regional Development: Review Study. Paper presented at the conference of College of Hospitality International Scientific Conference on Hospitality, Tourism and Education, Praha. 


\section{JOURNAL OF TOURISM AND SERVICES}

Issue 12, volume 22, ISSN 1804-5650 (Online)

www.jots.cz

\section{Brief description of Author/Authors:}

\section{Ing. Milena Botlíková, Ph.D.}

ORCID ID: https://orcid.org/0000-0003-2390-2165

Affiliation: The Institute of Gastronomy, Spa Management and Tourism, Faculty of Philosophy and Science v Silesian University in Opava, Masarykova třída 343/37, 746 01, Opava, Czech Republic, https://www.slu.cz/fpf/cz/.

Email: milena.botlikova@fpf.slu.cz.

The author focuses on the issue of tourism, regional issues in the context of sustainable development. She is the author and co-author of more than 40 articles in WoS databases. 